Meta

Journal des traducteurs

Translators' Journal

\title{
Translation in Romania: Steps towards recognition and professionalization
}

\section{Anca Greere}

Volume 55, numéro 4, décembre 2010

De la localisation à la délocalisation - le facteur local en traduction From Localization to Delocalization - The Local Factor in Translation

URI : https://id.erudit.org/iderudit/045692ar

DOI : https://doi.org/10.7202/045692ar

Aller au sommaire du numéro

Éditeur(s)

Les Presses de l'Université de Montréal

ISSN

0026-0452 (imprimé)

1492-1421 (numérique)

Découvrir la revue

Citer cet article

Greere, A. (2010). Translation in Romania: Steps towards recognition and professionalization. Meta, 55(4), 789-816. https://doi.org/10.7202/045692ar
Résumé de l'article

Le présent article est un état des lieux de la traduction en Roumanie, en particulier depuis 2007, année de l'accession de ce pays à l'Union européenne. Nos recherches se concentrent sur les éléments structurant le marché et la profession. Elles ont pour objectif d'expliquer comment trois facteurs (intégration régionale, action universitaire et participation des professionnels) se sont conjugués pour mettre en place, en un temps relativement bref, un marché digne de ce nom et de mieux en mieux reconnu à l'échelle européenne et mondiale. Trois questions-clés sont envisagées : prise en compte des problématiques de la traduction dans la population et à l'université, reconnaissance socio-économique des métiers des langues, et formation d'une conscience professionnelle collective considérée comme un marqueur de professionnalisation. Pour mieux approfondir ces questions, nous nous penchons successivement sur les principes sur lesquels s'est bâtie la situation actuelle, les évolutions survenues en matière de formation, les pratiques en vigueur sur le marché, et les relations à la fois professionnelles et universitaires avec le reste de l'Europe.
Ce document est protégé par la loi sur le droit d'auteur. L’utilisation des services d’Érudit (y compris la reproduction) est assujettie à sa politique d'utilisation que vous pouvez consulter en ligne.

https://apropos.erudit.org/fr/usagers/politique-dutilisation/ 


\title{
Translation in Romania: Steps towards recognition and professionalization
}

\author{
ANCA GREERE \\ Babeş-Bolyai University, Cluj-Napoca, Romania \\ anca.greere@softwaredesign.ro
}

\begin{abstract}
RÉSUMÉ
Le présent article est un état des lieux de la traduction en Roumanie, en particulier depuis 2007, année de l'accession de ce pays à l'Union européenne. Nos recherches se concentrent sur les éléments structurant le marché et la profession. Elles ont pour objectif d'expliquer comment trois facteurs (intégration régionale, action universitaire et participation des professionnels) se sont conjugués pour mettre en place, en un temps relativement bref, un marché digne de ce nom et de mieux en mieux reconnu à l'échelle européenne et mondiale. Trois questions-clés sont envisagées: prise en compte des problématiques de la traduction dans la population et à l'université, reconnaissance socio-économique des métiers des langues, et formation d'une conscience professionnelle collective considérée comme un marqueur de professionnalisation. Pour mieux approfondir ces questions, nous nous penchons successivement sur les principes sur lesquels s'est bâtie la situation actuelle, les évolutions survenues en matière de formation, les pratiques en vigueur sur le marché, et les relations à la fois professionnelles et universitaires avec le reste de l'Europe.
\end{abstract}

\section{ABSTRACT}

The article proposes a survey of the Romanian context with regard to the translation profession, especially with reference to directions of development after 2007, i.e., the year of Romania's accession to the EU. The research focuses on the configuration of the Romanian translation market and community in order to understand how the combination of international integration, academic efforts and involvement of professionals have made it possible to generate in a relatively short time a genuine marketplace and one that is rapidly making its mark on the European and international levels. The key questions are related to the level of awareness of the general population and academic institutions regarding translation market issues, the degree of recognition of language professions on a social and economic level and the extent to which professionalization has taken place to include a collective professional conscience. To these aims the following aspects will be reviewed: the underlying principles that build up the current context for translation in Romania, the developments in training, market practices and the relation to the European profession and academic environment.

\section{MOTS-CLÉS/KEYWORDS}

marché de la traduction, formation en traduction, métiers de la traduction, déontologie de la traduction, tendances du développement en Roumanie translation market, translation training, translation profession, ethics in translation, Romanian development trends

\section{Introduction}

The Romanian translation scene has witnessed successive stages of development guided by cornerstone events such as the 1989 Romanian anticommunist revolution 
and the 2007 accession to the European Union (EU). Both these events have had an impact on translation priorities and translation practices.

If before 1989 translators were predominantly involved in literary translations, this changed significantly after 1989. With the free market, more opportunities for international collaboration emerged and the specialized translation market flourished. In 1991, translator training was set up in Cluj-Napoca, soon to be extended to interpreter training with guidance from European academic and professional partners. In the years to follow, other universities devoted full or partial curricula to translator training. The translation of the acquis-communautaire, project overseen by the European Institute of Romania, ${ }^{1}$ represented a great challenge for the Romanian translation community and also an opportunity to develop terminology tools, teamwork practices and a quality-driven professional conscience. The accession to the EU, and Romanian becoming an EU official language, opened up new possibilities as many translators applied for the European Personnel Selection Office (EPSO) recruitment competitions or expressed interest in the call-for-tenders for freelancers to receive outsourced commissions from EU institutions. Simultaneously, on the national level, language professions were consolidating their positions in relation to the economic and social environment. Professional associations were founded, codes of practice were elaborated, translation and interpreting became explicit economic activities for companies to undertake, professional classifications made room for the occupations of 'translator' and 'interpreter,' and the European standard EN 15038 was adopted nationally. However, if education and the market were forging forward in tune with European developments, the legislation involving translators (and implicitly the procedure to authorize translators) is still lagging behind, sending off mixed signals about the exigencies of these professions.

This study proposes to analyze the steps that led to the present situation in Romania with regard to translation-related activities and to determine the aspects which are now consolidated and which require further development, before we can safely report that the Romanian translation scene is developing at a comparable pace with the European market and is embracing similar quality-driven principles. To establish the context and to present a clear image of the aspects that influence the general perception regarding translation the following aspects will be considered: differentiation of professional profiles, legislative stipulations vis-à-vis the awarding of official professional recognition by Romanian authoritative bodies and the prerogatives that encompass the status of "authorized translator." I then move towards training initiatives to explain the developments on the academic level and the degree to which market requirements are being accommodated in training programmes. The business and the profession are other points of focus as I investigate the preferred business arrangements and the consolidated business mechanisms which have provided the catalyst for determining a sense of professionalization for translation practitioners and their subsequent impulse to build a community and develop and consolidate a professional mentality based on quality and ethics. Not least, I also look at the European context and the way the Romanian market will find opportunities for the development of translation-based collaborations. I conclude by identifying points of further development on the market and in training which will secure the directions pursued so far and by identifying points of complementary research necessary to reiterate the results of studies conducted and to offer supplemental validation of the conclusions derived. 
Given that previous research into these topics is scarce and very fragmented in terms of focus, it is very hard to achieve a comprehensive, complete and fully reliable overview of the situation. To present a wide-ranging image, I evaluate legislative Acts, different Codes elaborated by professional associations and other relevant documents pertaining to Romanian authoritative bodies. I also draw on surveys conducted by the Romanian Translators Association, the Association of Romanian Translation Agencies and on results of research projects I coordinated in the Babeş-Bolyai University of Cluj-Napoca, some as yet unpublished. For the first set of research instruments, the positive research implications are given by the fact that information is analyzed at the source without subsequent interpretation by other researchers. However the drawback to presenting these documents is determined by the current rapid changes taking place in Romania, not least as triggered by the international economic crisis (started in 2008), which will determine legislative amendments and successive stages of document updatings in the very near future. In what regards the surveys, the positive side of working with surveys is that one gets to feel the pulse of the market as such, the drawback for our study is represented by the apparently low response rate for the surveys and the difficulty to establish what a relevant rate would be. This difficulty is given by the fact that it is yet unknown what the number of active translators is on the market; the listing on the site of the Ministry of Justice adds up to almost 30,000 translators, however on professional membership lists and forums, no more than 3,000 translators are listed. As response rates for the surveys quoted fall slightly short of 300 , it is difficult to acknowledge if this represents $10 \%$ of the active translator population or $1 \%$. On the other hand, the profiles of respondents are sufficiently varied (in terms of sex, age group, training profile, experience on the market) to relevantly indicate a snapshot picture of the approaches adopted and the trends the market is moving towards, making the conclusions of this research noteworthy.

\section{Translation in Romania - the context}

Deeply embedded in the Romanian culture are some biased views regarding translation such as: translations can and may be carried out by anyone who claims to know a foreign language; translations into the foreign language are not deontologically unacceptable; translation will first and foremost be a collateral activity rather than a profession; translation and interpreting are the same activities bar the communication channel; lack of domain-knowledge will not impede on the translation task; an authorization is the only indicator of quality and only the holder of such an authorization is a professional. In the past 10 years such attitudes have greatly changed. However they seem to resurface in different aspects of the professional activity, undermining or slowing down specific positive initiatives.

In what follows, I focus on aspects that by tradition underlie approaches adopted in Romania, but which, at this stage of market and community development could be said to impede on the free expansion trend. Such restraints are represented by: (1) a fuzzy differentiation between professional requirements and profiles, (2) authorization procedures that are wrongly interpreted as sole forms of professional recognition, (3) legal stipulations that claim more than the translation practices they were designed for. 


\subsection{Translation and Interpreting}

Romanian legislation does not acknowledge the underlying differences in the two professions, bar the medium of communication oral vs. written. Romanian training programmes and market practices show that although there is awareness of the fact that translation and interpreting are two different professions, entailing two distinct sets of competences and being performed by different specifically trained individuals, for various reasons, not least financial ones, translation and interpreting are not treated separately. In contrast with the legislative approach, the Classification of Occupations in Romania does, however, indicate two distinct entries for translator and interpreter.

Law 178/1997 regarding the activity of translators and interpreters employed by legal authorities including the Ministry of Justice, courts and tribunals, notary public offices and attorneys-at-law does not distinguish in any way between the two professions, throughout the legal text 'and/or' appears between the word translator and interpreter. Similarly, the authorization procedure by dossier practised by the Ministry of Justice results in the issuing of an authorization, which officially appoints the holder to perform translation and interpreting tasks, without having tested or verified in any way the distinctive competences required. ${ }^{2}$ This approach is misleading to some clients and enables translators with a lower sense of responsibility vis-à-vis the profession to take on tasks for which they know they are not properly qualified.

Universities throughout Romania are looking up to European initiatives (see also 2.1.) where specialized translations and conference interpreting are solely tackled at master's level within distinct programme structures with a view to preparing independent professionals for specific market needs. However, for now, for reasons that have to do with administrative procedures, financial constraints and lack of qualified staff for a successful implementation of distinctive master's level programmes, some universities stop the training altogether after the introductory level (undergraduate) without proposing advanced training in either profession. Thus many students will only be introduced to translation and interpreting practices without becoming fully aware of the different requirements and exigencies of the two professions or, indeed, that they are two distinct professions. Even universities which do offer master's level training often choose to either refrain altogether from dealing with interpretation at a high level and propose a continuation of studies at master's level only for translation and terminology, or they will include interpretation alongside translation training as part of the same programme. Only very few Romanian universities (Babeş-Bolyai University of Cluj-Napoca, ${ }^{3}$ University of Bucharest) have two distinct master's programmes corresponding to the two professions.

The marketplace goes along with the legislative and educational trends and accepts the fuzzy professional differentiation, as this will result in benefits for some translation practitioners who take on interpreting tasks to supplement their income and/or provide a 'complete' service. The 2007 survey of the Romanian Translators Association indicates that more than half of the active translators (54\%) engage in interpreting activities, as well. On the opposite trend, the remainder frequently refuse to interpret even in liaison or public-service contexts invoking lack of specific competence, which, in fact, is a good marker of professional self-awareness.

In spite of this apparently static and convenient attitude considering the two professions as one we do witness developments in other spheres of the Romanian 
professional environment. Indeed, the most recent updatings of the Classification of Occupations in Romania attributes a section to language professions where distinct codes have been provided for translator (244406) and for interpreter (244402). This is a strong message that can be taken as referential. ${ }^{4}$

\subsection{Authorization of translators}

Currently, Romanian procedures entail two distinctive practices that allow translators to obtain an official professional status. The Ministry of Justice authorizes translators to work for legal authorities such as the Ministry, courts and tribunals, notary public offices and attorneys-at-law. The Ministry of Culture issues translation certificates for different domains on the basis of a testing procedure. Graduates of undergraduate language degrees (Philology or Applied Modern Languages programmes alike) will submit an application file to the Ministry of Justice to obtain their authorization. So will graduates of bilingual high schools (according to Law 110/2005 amending Law 178/1997) while graduates of undergraduate non-language degrees will take a translation test administered by the Ministry of Culture in the domain of their choice to obtain their certification as translators. If non-language degree graduates want to obtain the authorization from the Ministry of Justice, they have to take the Ministry of Culture test in the legal domain and present this certification on application to the Ministry of Justice. After submitting the application file, the applicant is issued an authorization which covers translation and interpreting from and into the foreign language the university degree is in or from and into the foreign language that was tested by the Ministry of Culture.

As stands, the authorization procedure presents a number of flaws that derive from insufficient consideration of market and training mechanisms. Philology university graduates, not to mention bilingual high school graduates, ${ }^{5}$ do not train in the legal domain, nor do they acquire during their training any interpreting skills. Hence they are underqualified for the activities they are authorized to perform. Under the Bologna process, 3-year undergraduate programmes in general and even those that train in Applied Modern Languages can focus on development of general language and cultural skills offering merely introductory notions for professional profiles such as translator and interpreter. In these conditions graduates of first-cycle Bologna programmes are not sufficiently equipped to tackle specialized translations or court interpreting.

Given this lax procedure which entails no evaluation of specific translation competences, many language graduates will seek out the authorization whether they intend to become translators or not, transforming translation into a safety net rather than a profession. As a result, their responsibility vis-à-vis the profession is greatly misinterpreted and trial-and-error approaches for newly-authorized translators are common. Furthermore, many will apply for the authorization by the Ministry of Justice knowing explicitly that they do not intend to perform translations for legal authorities, but they are looking for some form of acknowledgement of professional status to present to clients and this authorization can suit the purpose.

Consequently, the authorization has become misleading also for other categories of stakeholders: (1) clients misrepresent this authorization as a marker of quality and are keen to have authorized translators perform their tasks at higher fees, if need be, 
(2) candidates for training programmes often fail to see the relevance of the initial undergraduate or advanced master's level training if they can become translators without going through three to five years training.

Amendments to this procedure are strongly called for (Greere and Tătaru 2008:119-120). If in the past no specialized training could account for specific competence development, currently the education scene does provide programmes where advanced level competences are developed. Hence, any authorization of translators and/or interpreters should be based on the evaluation of professional competences and domain-related expertise as developed through successful completion of specialized professional training and/or on documented experience on the market. In the foreseeable future viable alternatives to the authorization of the Ministry of Justice could be represented by affiliations to professional associations with strict membership eligibility criteria and/or certification for compliance with the standards adopted on the market, e.g., SR EN 15038. In this context, the authorization by the Ministry of Justice would strictly serve the purpose of translations and interpreting for legal authorities; anyone wishing to focus on a different section of the market would refer to other forms of recognition of professional status, as indicated above. Such a change of perspective would move the focus from this authorization as the only referential instrument of professional recognition and would enable stakeholders to break away from the alluring status the authorization now enjoys into shaping an unbiased market where recognition is a clear consequence of professionalization.

\subsection{Legislation in force}

Romanian legislation regulating the activity of translation and interpreting per se is strictly focussed on procedures that are applicable in contexts where authorized translators and interpreters are required for the linguistic transfer of communication instances with legal value. However, such legislative stipulations put their (frequently unwanted) imprint on the market at large with translators applying for 'official recognition' even for contexts where other approaches might be more recommendable.

Law 178/1997 stipulates employment mechanisms to be applied by the Ministry of Justice, courts of justice, notary public offices and lawyers when services of translation and interpreting are sought, the eligibility criteria for the authorization of translators and interpreters, the authorization procedure the Ministry of Justice is to follow for the authorization of translators and interpreters working for judicial bodies, termination circumstances for the authorization. Law 178/1997 also indicates the standard fees for translation and interpreting services as delivered for Romanian judicial institutions. There have been multiple amendments to this law with a view to providing updated fees in accordance with economic tendencies ${ }^{6}$ and for the purpose of refining the authorization procedure $\mathrm{e}^{7}$ and enlarging the recruitment pool for translators/interpreters used by judicial authorities. ${ }^{8}$ Consequently, fees have been increased and decreased legislatively in the past ten years (see 3.2) with Law 110/2005 clearly stipulating that decisions pinpointing establishing fees would be issued regularly on the basis of governmental indexations following economic trends. The authorization procedure has also suffered changes (see 1.2.): if initially Law 178/1997 stipulated as one of the requirements for the completion of an undergraduate university degree in languages, Law 110/2005 enables graduates of bilingual high schools 
to obtain the authorization without any university training, while Law 286/2005 eases the requirements further, in what is already a lax procedure, enabling any 'trustworthy person who knows the languages for translation or interpreting' to step in and take on such tasks if legal authorities are at difficulty finding authorized translators for a particular commission. ${ }^{9}$

Methodological aspects vis-à-vis the production of authorized translations are regulated by Law 36/1995 regarding the Notary Public activity. Annex 1 of this Law gives instructions in regards to aspects of textual transfer and target text production. According to this Annex only authorized translators are allowed to translate and/or interpret for notary public offices and their names must be listed on the site of the Ministry of Justice. Such translators may be employed as freelancers or full time staff by the Notary Public office. As a general methodological rule, the meaning of the source text will be preserved and will be rendered through expressions specific to the target language. Translations may be done as excerpts only or as full texts from and into Romanian, and from a foreign language into another foreign language with the provision of a Romanian intermediary document. The source text language must be clearly indicated in the translation and non-verbal elements (photographs, signatures, etc.) must be transferred in explicit verbal form in the target text. Names of persons or geographical names must be typed by maintaining their orthographic specificity. Translators must refuse to translate texts that are illegible or contain corrections. Each authorized translation will be accompanied by a certification and legalization procedure which will be documented through specific textual formulas applied at the end of the translation by the authorized translator and the Notary Public.

Other legislative acts are regulatory for the activity of translators but are not strictly directed towards this activity, namely legislation regarding types of business organizations ${ }^{10}$ and regarding the activity of sole-traders. ${ }^{11}$

\section{Translation in Romania - the training}

University-based training as well as training offered by professional bodies is crucial for enhancing the composition of the translation market and ensuring an appropriate degree of professionalization. Completion of these programmes will result in a recognized professional status; the different forms of certification issued on completion stand proof of the type and level of competences that have been acquired.

Romania is now developing a training culture for translators. Specific programmes are up and running but there are still mentality changes to be fought for. Such changes encompass the perception of future trainees vis-à-vis the training, the prospects that it offers and the way the training is organized to render it successful. In this sense, consideration of market trends and collaboration between academics and professionals are prerogatives of any relevant training and Romania is striving to accommodate training requirements to this aim. What is more, continuous professional development is slowly being acknowledged as an indispensable facet of professional life. 


\subsection{Training in Higher Education Institutions - undergraduate and postgraduate}

Traditionally, in Romania, translation was tackled within Philology departments with a focus on literary translations. With the academic year 1991-1992 the first department of Applied Modern Languages was set up in Cluj-Napoca following the French Langues Étrangères Appliquées (LEA) model. In the years to come, other universities in Romania followed suit and offered Applied Modern Language training with a focus on translation and interpreting both at undergraduate and master's level.

Applied Modern Language training was officially acknowledged in 2005 when the Romanian nomenclature of higher education domains and specializations was reviewed and the amended version published in the Romanian Official Gazette no. 766/ 23 August 2005 presented a new division for language training. Accordingly, we find two distinctive domains: Language and Literature (former Philology departments targeted predominantly towards language teacher training) and Applied Modern Languages with two subordinate specializations: 'Applied Modern Languages' and 'Translation and Interpreting.'

In the pre-Bologna structure, the undergraduate programme was designed to offer a complete study programme with learning outcomes that triggered the development of the whole range of translation and interpreting competences (Greere and Tătaru 2008: 114-117) and with a clear focus on a number of domains of specialization (e.g., law, business, tourism). In this context, the master's programme proved a non-compulsory stage in the training of professionals and only those very keen on continuing their studies or those having some professional experience in need of proper training were interested in enrolling. Hence, the one-year master's structure could not prove a very viable training prospect for graduates of other programmes than Applied Modern Languages as students were often required to make use of the knowledge and skills acquired in their undergraduate years.

The situation changed radically with the new Bologna programmes (Greere 2010: 14). It is clear that, under the Bologna reform, undergraduate programmes are insufficient to present the graduate with competences that circumscribe a profession and which will enable the graduate to successfully penetrate the market in other than subordinate positions. Romanian graduates have yet to adjust to the new educational perspective and view the master's programme as an obligatory stage of professional enhancement.

Such a change in mentality must be driven from the institutional side and Romanian universities have taken the challenge. Currently, the DOCIS project managed by the Romanian Agency for Qualifications in Higher Education and Partnership with the Economic and Social Environment ${ }^{12}$ proposes the re-evaluation of qualifications descriptors in Romanian HE. Under the DOCIS umbrella, a number of 17 universities delivering Applied Modern Language training have come together in a consortium to update and further develop the competence framework underlying curriculum development for undergraduate programmes of 'Applied Modern Languages' and 'Translation and Interpreting.' In April 2010, a consensus was reached regarding the learning outcomes of undergraduate programmes as opposed to master's level programmes. It was specifically agreed that a clear-cut distinction should be made in terms of level of development for particular competences and that 
if the undergraduate programmes were to focus more on linguistic and cultural skills, in the time frame allocated such programmes could strictly inform and familiarize the students regarding professional perspectives and market prospects. It would be misleading for students if they were made to believe that on completion of the undergraduate programme they would become independent professionals. The master's programme would then clearly focus on completing professional expertise by proposing a curriculum that would include topics such as marketing, management, computer assisted translation tools, translation and terminology for specialized domains, etc. and extended opportunities for interaction with the professional world. The guidelines of the European Master's in Translation (EMT) Network conducted by the Directorate General for Translation of the European Commission ${ }^{13}$ would be recommendable tools for developing and enhancing programmes at master's level. Additionally, the Visiting Translator Scheme of the Directorate General for Translation of the European Commission ${ }^{14}$ would serve as support for new or running programmes especially if these were striving to adhere to the EMT network. To date, following a strict selection procedure, the EMT network includes only one Romanian member, the European Master's in Translation Studies and Terminology of the BabeşBolyai University in Cluj-Napoca. ${ }^{15}$ However other universities have also expressed interest in developing their programmes along EMT guidelines and many Romanian universities have already benefitted from a VTS visit. Possibly, one of the EMT criteria most difficult to accomplish, especially due to academic constraints on the status of the teaching staff, is to have professionals with experience training on the programmes.

The aim is clear, if Romania is to offer quality training for language professions, universities and internal bodies have to move more closely towards European models and become part of the European agenda for language training. The Babeş-Bolyai University has already made significant progress in this direction. In Cluj-Napoca, under the Bologna reform, the Applied Modern Languages undergraduate programme has already been adjusted to focus predominantly on the development of language and culture skills, pre-requisites for further adequate professional development. Thus, more specialized training, i.e., domain specific and CAT related, has been incorporated in the master's structure. Additionally, on recommendations of EU institutions regarding the professions of translator and interpreter, two master's programmes were accredited dealing specifically with translation - terminology and conference interpreting, giving a clear indication to students and other stakeholders that two distinct professions are being trained for.

Noteworthy is also the fact that the Romanian Agency for Quality Assurance in Higher Education ${ }^{16}$ is sensitive to changes taking place within this domain at national and European level while it is currently reviewing the accreditation standards for higher education programmes training translators and interpreters. Alongside other recommendations (Greere 2008: 89-91) regarding learning outcomes to be clearly differentiated for undergraduate and postgraduate training to be staged out properly according to the level of difficulty and the competences involved, the Romanian Agency for Quality Assurance in Higher Education is also considering to encourage professional involvement in higher education training with a predominant vocational component. If until now, master-level programmes could only employ academically ranked teaching staff (holding a $\mathrm{PhD}$ and a minimum rank of lecturer) the new 
standards are intended to make room for different forms of collaboration with the professional community.

Another significant change at the level of higher education regards the focus on the languages being tackled. As a requirement for Applied Modern Languages programmes students will enrol with two foreign languages to be dealt with as $\mathrm{B}$ languages and can take up a $\mathrm{C}$ language during their studies. Common $\mathrm{B}$ languages are English, German, French, Spanish and Italian, with other more exotic languages making their way in as C languages: Oriental languages - Chinese, Japanese, Korean; Nordic languages - Swedish, Finnish, Norwegian, Danish; Border languages Bulgarian, Serbian, Turkish, Ukrainian, Russian, ${ }^{17}$ emerging minority languages, e.g., Romanian Sign Language and Romani, as well as other languages such as Arabic, Greek, etc. If traditionally, higher education foreign language programmes in Romania focussed on the development of active competences in the foreign language with no (or very little) concern for Romanian language development, today for Applied Modern Languages programmes there is a general understanding that Romanian needs to become an integral part of the curricula as translation graduates will succeed on the market if and only if they possess very strong Romanian language competences, also in specialized fields. The misconception that to be born into a language will render one an expert has been overcome with academics, students and quality assurance experts acknowledging the need for training to equally address native language competence along with foreign language competence. After all, the Romanian language is the licence of Romanian translators for the international market, a fact which transpires strongly from EU institutional policies, as well.

All these developments point towards a higher education area where language professions are well understood and where effort is being made to adjust programmes accordingly. In spite of the national authorization procedure of translators and interpreters by the Ministry of Justice which clearly discourages postgraduate training, if not tertiary education altogether (see above 1.2), Romanian translator training is coming of age, with programmes that are driven by European guidelines and with trainers that have the availability and openness to move away from traditional philology-based translation training towards highly specialized training with appropriate methodology. This development is bound to make a difference, if only in the long run, on authorization/certification practices and the market composition.

\subsection{Training by Professional Associations - continuous professional development}

For now, continuous professional development is undertaken successfully by the Romanian Translator's Association (ATR) which in the past 6 years has proposed a number of training seminars with national participation. Topics have varied taking into consideration specific needs expressed by both the professional and academic communities. In total more than 1000 translators and interpreters, members and non-members of the Romanian Translators Association, have received continuous professional development training in computer-assisted translation tools, editing and revision, legal translations, marketing and management skills, the application of the SR EN 15038 standard, etc. The Romanian Translators Association also proposes a close relationship with higher education training and in 2009 launched a continuous 
professional development initiative directed towards the academic community of translator and interpreter trainers organizing a seminar on 'Training of trainers of translators and interpreters.' Participants comprised 37 academics from 11 universities, as well as company-based trainers. ${ }^{18}$ In 2010, the Romanian Translators Association also launched a series of online continuous professional development seminars and workshops specifically aimed at reducing costs for participants and making continuous professional development more available and less timeconsuming. The schedule for the training programmes is listed one year in advance and considers feedback from contact sessions regarding utility and necessity of particular continuous professional development topics. ${ }^{19}$

Other opportunities for continuous professional development exist as promoted by professional or academic organizers. For example, continuous professional development for language professionals is offered on demand to national and international organizations by the Babeş-Bolyai University as listed in the CPD database ${ }^{20}$ of the Universities Contact Group, an initiative of the IAMLADP - International Annual Meeting on Language Arrangements, Documentation and Publications and the Association of Romanian Translation Agencies proposes an agenda for 2010 including continuous professional development for their members.

\subsection{Translation-focussed research in Higher Education}

To date university-based research on translation is predominantly undertaken by academics teaching in Applied Modern Language departments and $\mathrm{PhD}$ students. If the research of academics may be focussed on translation and terminology issues per se, $\mathrm{PhD}$ students will undertake research topics that are convergent with the field of translation studies but fall under the more general umbrella of linguistics. This is generally due to the fact that $\mathrm{PhD}$ coordinators cover a wider area of study having been appointed by a national committee of the Ministry of Education after they achieve full professor status in the Romanian academic system. As Applied Modern Language studies and Translation Studies are relatively new to the Romanian education area and only officially acknowledged in 2005, no appointments for professorship have yet been made in the specific domain of Applied Modern Languages, hence PhD research is conducted still under the supervision of Professors in the field of Linguistics and $\mathrm{PhD}$ titles are awarded for Linguistics.

While the Romanian academic background possesses a rich literature resulting from contrastive linguistic research conducted before 1989 looking at Romanian vis-à-vis other languages, this research is not translation oriented and excludes the inherent mechanisms that make translation such a complex activity. In terms of research topics currently addressing more specific translation and interpreting issues, the most common have to do with terminology or comparative/contrastive language studies for the purpose of developing appropriate transfer solutions as part of translation activities; methodological aspects also come into play focussing on Romanian in different language combinations. Such research is extremely important to establish the issues that make translations with Romanian problematic and to develop solutions for overcoming such difficulties.

In spite of the importance of current research, adequate reception of research findings is often hindered by ad-hoc distribution mechanisms for publications resulting 
from translation research and by the publication of the research findings in foreign languages, this being a requirement of major journals in Romania. If $\mathrm{PhD}$ theses are published by publishing houses with no national distribution network, the publications will reach intended recipients on an ad-hoc basis and frequently after a long period of time. Although this research focuses on Romanian as a language of translation the majority of research findings are actually published in an international language: English, German, French or Spanish or in the language that is being contrasted to Romanian. Even if allegedly this approach allows national Romanian journals to be received internationally, it makes the explicitation of the research findings difficult as it involves substantial glossing and it greatly discourages communication amongst Romanian academics and professionals on specific research topics that have to do with Romanian as a language of translation. Subsequently, at least for the present, the exchange of ideas emerging from research on translations with Romanian is limited to reception in foreign languages, except for very few instances and is delayed by untimely absorption of research results. These drawbacks, however, do not overshadow the relevance of the findings and the importance of the research being conducted.

\section{Translation in Romania - the business}

The development of a profession within national boundaries is clearly influenced by the recognition of that profession on the general economic scene of a particular country and the business opportunities that arise for the members of that particular professional community in relation to national economic development.

Market surveys indicate that the business of translation on the Romanian market can be quite profitable especially after $2007,{ }^{21}$ also considering other convergent services; the number of translation companies has grown, fees are comparable to the European market, in particular cases, and there is preoccupation amongst professionals to establish a market average; and turnovers allow freelancers and companies to live off this activity alone and even make a substantial profit, in some instances.

In order to circumscribe the business of translation we find that a number of legislative requirements come into play, some holding down the free evolution of the market by imposing fees and types of business organizations. On the other hand, one of the most significant developments in upgrading the activity of translation to a business in the Romanian context was the acknowledgement of translation in the Classification of Romanian Economic Activities as a high-impact, self-providing activity. If, until 2008, translations were included in the Classification of Romanian Economic Activities under '7483 secretarial, typing, photocopying and translation activities' (our emphasis), currently businesses can choose as their main object 'written and oral translation activities,' separately encoded as 743 .

\subsection{Business organizations for translators}

Translation activities are generally conducted by freelancers, i.e., sole-traders, or translation companies. Currently, there are over 30,000 listed authorized translators on the site of the Romanian Ministry of Justice ${ }^{22}$ (it is however not known how many are active, see also 1.2.) and almost 100 translation companies with a turnover of over 
25,000 euro per year according to the 2008 yearly analysis of the translation market of the Association of Romanian Translation Agencies. ${ }^{23}$ According to another survey conducted by the Romanian Translators Association in 2007, 73\% of the total 289 respondents were freelancers, $23 \%$ translation companies and $19 \%$ in-house translators and interpreters ${ }^{24}$ (Cobliş 2008:138). These figures are partially confirmed by another survey conducted in 2010 by the Babeş-Bolyai University where 229 respondents were $61.2 \%$ freelancers, $15 \%$ in-house translators, $11.5 \%$ owners of translation companies, $5 \%$ have a double status, i.e., freelancers and in-house translators. ${ }^{25}$

In order to register as a sole-trader one must provide as proof the authorization issued by the Ministry of Justice (see also 1.2 for details). To conduct translation activities companies will have to indicate in their Memorandum of Association the objects code ' 743 Written and oral translation activities' either as a main object or a secondary object of activity, without any proof of acquired translation competence.

Many translators who are authorized will prefer to register as sole-traders because this status is considered to provide professional independence and a more relaxed fiscal regime, hence it is more convenient in terms of time and task management, as well as taxation. Moreover, as sole-traders, translators have more professional flexibility and may more easily collaborate with more than one translation company. The major disadvantages of this business type are, of course, given by the fact that it is more difficult to attract major clients and to convince them of qualityrelated issues, such as the guarantee of the revision stage by another translator or the ability to manage large projects.

As a company, translation service providers frequently set up limited liability companies as opposed to the public limited companies. As in every civil law system, the former entails less registration bureaucracy and fewer initial investments (i.e., the start-up share capital is $200 \mathrm{RON}$ approx. $50 €$ ). Until 2009, a viable alternative for a company was the SME - Small and Medium Enterprise which presented some fiscal advantages, in the meantime these facilities have been amended making the small and medium enterprise no longer attractive. 2010 is bound to bring new taxation policies also for sole-traders and we may foresee for 2011 sole-traders grouping themselves into companies, which might lead to the balancing out of the current $70 \%$ sole-traders - $30 \%$ companies percentage scale.

\subsection{Fees on the Romanian market}

As for any developing market, fees vary considerably on the Romanian market depending on the type of business organization of the translation service provider and the type of translation task, be it non-specialized/general or specialized.

The standard unit for translation price quoting is still a matter of debate in Romanian professional settings. Whereas major translation service providers will use 'the word' as the translation unit for compliancy with the European market (also recommended practice by the Work Standards of Association of Romanian Translation Agencies ${ }^{26}$ ), other categories of translation service providers, including freelancers, will prefer the more traditional 'page' as the negotiating unit. However, the latter may become highly problematic for clients as Romanian translation service providers don't always have the same definition for a 'page,' hence, when quoting the price, some will refer to the page as a unit of 1500 characters - no spaces or 2000 
characters - no spaces or with spaces, which may loosely approximate into a page of 300 words or 30-32 lines. Translations of documents that are less than a page and require notarization will generally be treated as a one page document for price quoting purposes. A matter of debate may also be the text for the reference count, i.e., the source text or the target text. However, most translation service providers will relate to the ST.

Article 9 of Law 178/1997 on the authorization and payment of translators and interpreters working for institutions/bodies/entities with judicial authority indicates a fee of $10 \mathrm{RON}^{27}$ /per civil status document and $22 \mathrm{RON}$ per page (where a page is defined as 'format A4 double spacing') for notarized translations into Romanian and $30 \mathrm{RON}$ per page for notarized translations into a foreign language. The fees will be increased with a 50\% rate for oriental and other rare languages as well as for urgent commissions. Order 1291/2002 raises these fees to 41 RON for translations into Romanian and $56 \mathrm{RON}$ for translations into the foreign language. Ministerial Order $772 / 2009$ amending Law 178/1997 sets at article 1 paragraph b) a new but lower fee, i.e., 33.56 RON regardless of translation direction from or into the foreign language, and also redefines the standard page to mean "format A4, style Arial normal; font Arial; size 12; one-line spacing; one space in-between words; margins: $2.5 \mathrm{~cm}$ top $2.5 \mathrm{~cm}$ bottom, $2.5 \mathrm{~cm}$ left $-2.5 \mathrm{~cm}$ right." Besides this new definition of a standard page which undermines any attempts at reaching a commonly accepted denominator and one that could be adopted by the general market without any imposition on document re-editing, we may notice that the new fee does not follow in the least the economic curve in Romania, i.e., since 1997 the Romanian currency has depreciated almost $50 \%$, a depreciation which should have attracted a corresponding increase in the standard page rate indicated by the Ministry of Justice.

Outside of these legal guidelines, fees on the market for common languages fluctuate from 8-10 RON per page (practiced by students or collaborators who do not have a certified professional status) up to 50-60 RON for highly specialized translations performed by established translation service providers. Rare languages will be charged at higher rates, as are also translations commissioned by foreign clients. In these cases, fees will compete with those on the European and international market $(€ 0.07-0.15 /$ word) and will certainly be higher than the indicated national fees for common languages.

A pilot survey conducted by ATR in 2007 (unpublished) where translators were asked what they felt the recommended fees should be for translation services indicated a fragmented perception with three distinct fee ranges, each favoured by about $20 \%$ of respondents. Still agreement was reached for the lowest mark and the highest mark: for authorized translation the approved range was $15 \mathrm{RON}$ per page to $35 \mathrm{RON}$, whereas for specialized translations this range increased from $25 \mathrm{RON}$ per page to over 50 RON. More specifically, out of the 147 responses $29 \%$ opted for $14.5-24.5$ RON for an authorized translation, 30\% opted for 25-29 RON, while 19\% proposed fees in a range of 30-34.9 RON and 11\% suggested 35-50 RON as the adequate fee range. The same study indicates that for specialized translations these fees should move up above the $25 \mathrm{RON}$ indicator and range over the $50 \mathrm{RON}$ quote: $19 \%$ favoured $25-29 \mathrm{RON}$, $26 \%$ chose $30-34.9$ RON, $23 \%$ find rates of $35-50$ recommendable and $22 \%$ feel that $50 \mathrm{RON}$ and more should become the guideline for specialized translations. 


\subsection{Turnover from translation activities}

No data exists to indicate what the turnover of sole-traders practising translations is, ${ }^{28}$ and because we cannot estimate how many of the registered sole-traders exclusively earn their living from translation activities, it would be quite difficult to collect such data. However, translation companies have been closely scrutinized regarding their turnover and market share over the past 8 years, i.e., since 2002, by the Association of Romanian Translation Agencies which publishes yearly analyses of the Romanian translation market by updating financial data from the reports listed on the site of the Romanian Ministry of Finance. ${ }^{29}$

According to this survey, ${ }^{30}$ in 2008 there were 99 translation companies with a turnover of over $€ 25,000$. Out of these 31 had a turnover up to $€ 50,000,53$ ranged from $€ 50,000$ to $€ 300,000$ in turnover and 15 had turnovers of above $€ 300,000$. The total turnover of these 15 companies reaches $€ 12,000,000$ and 3 of them have a turnover of approximately $€ 1,500,000$ /year/company or more. The general conclusion of the 2008 survey is that the increase of the Romanian translation market turnover was $20.3 \%$ as compared to the year 2007 .

Of significance is the evolution of the market from 2006 to 2007, a timespan that incorporates the date of Romania's accession to the EU. Consequently, the 2007 figures as compared to those of 2006 are indeed spectacular: an $85.5 \%$ rise in total turnover for all company types, a doubling of turnover figure from $€ 5.4$ million to $€ 10.1$ million for companies above the $€ 300,000$ turnover mark, while companies with turnovers in-between $€ 25,000$ and $€ 50,000$ more than tripled their overall turnover highlighting an increase of $260 \%$. The number of companies registered on the market also increased for companies with turnovers under $€ 300,000$ almost doubling from 2006 to 2007 , from 40 to 73 such companies. ${ }^{31}$

TABLE 1

Turnover in 2006-2008

\begin{tabular}{|l|c|c|c|c|c|c|}
\hline & $\begin{array}{c}\text { Number of } \\
\text { companies } \\
\text { (above } \\
300,000 €)\end{array}$ & Turnover & $\begin{array}{c}\text { Number of } \\
\text { companies } \\
(50,000- \\
300,000 €)\end{array}$ & Turnover & $\begin{array}{c}\text { Number of } \\
\text { companies } \\
(25,000- \\
50,000 €)\end{array}$ & Turnover \\
\hline 2006 & 11 & $5,460.373 €$ & 26 & $2,890,188 €$ & 14 & $510,589 €$ \\
\hline 2007 & 15 & $10,182,310 €$ & 44 & $4,880,870 €$ & 29 & $1,069,661 €$ \\
\hline 2008 & 15 & $11,997,809 €$ & 53 & $5,906,282 €$ & 31 & $1,122,720 €$ \\
\hline
\end{tabular}

\subsection{Services and clients}

The 2007 survey of the Romanian Translators Association provides information on the nature of collateral services that are being offered by translation service providers in Romania. We find that in addition to written translation services (99\%), translations into B or C languages (78\%) and authorized translations (69\%) TSPs engage commissions of revision/proofreading (60\%), interpreting (54\%), localisation (20\%), subtitling (14\%), and technical writing (12\%) (Cobliş 2008:140). 
FiguRE 1

Services offered by Romanian Translation Service Providers ${ }^{32}$

Other value added services Translation into $\mathrm{B}$ or $\mathrm{C}$ languages

Technical writing Localisation

Authorized translation

Subtitling

Revision/proofreading Interpreting

Written translation

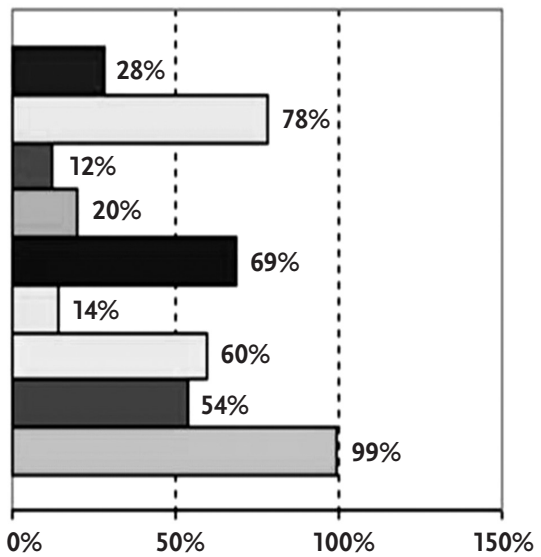

Authorized translations, i.e., notarized, of individual documents have always represented a fair share of translation commissions on the market. Every translator authorized by the Romanian Ministry of Justice is bound to offer such services: after all this is the reason the authorization is issued. The fact that services of localisation, subtitling and technical writing have taken their share of the market is a positive indicator of market development towards diversity. The $60 \%$ quota for revision/proofreading indicates an obvious concern for quality by clients seeking out this service. However this result also confirms that for the moment, in spite of the SR EN 15038 recommendations where revision is a stage of the translation process rather than a distinct service, practices on the Romanian market still consider revision as a distinct service, in addition to the translation task per se and paid separately. This is also confirmed by the fact that the market presents mainly freelancing, rather than teamwork activities, and for freelancers revision remains a stage in itself. The $54 \%$ rate for interpreting highlights the insufficient distinction between the profession of translator and that of interpreter on the Romanian market and the fact that translators will take on interpreting tasks and interpreters will take on translation tasks to ensure work and to supplement their income. In particular, novice authorized translators fall into this particular trap, ignorant of the differences in competence profiles for the two professions; in time, a more responsible attitude is developed and translators will often refuse interpreting tasks if these entail more than liaison. Most alarming, however, is the $78 \%$ result for translations into the $\mathrm{B}$ or $\mathrm{C}$ language, a practice traditionally endorsed by Law 178/1997 and which continues to represent a large share of the market. If organizations and translation service providers worldwide deontologically identify the only acceptable translation direction as that into the dominant/ A language with translations into the $\mathrm{B}$ or $\mathrm{C}$ languages looked down on by many professional codes throughout the world, in Eastern European countries as well as Romania this practice is still widely observed as clients continue to solicit such services ignoring or disregarding inherent quality issues and placing financial considerations above quality principles (Cobliş, 2008: 140).

The same survey conducted by the Romanian Translators Association inquires into the categories of translation service buyers and highlights the fact that respon- 
dents work with direct clients legal entities (211 out of 900 responses), direct clients natural persons (208 responses), translation companies, agencies and bureaus (181 responses), notary public offices and lawyers (110 responses), public institutions, i.e., courts, police bodies, etc. (82 responses) and publishing houses (a very low 54 out of 900) (Cobliş 2008: 141). The results for translation service commissioner typology cross-tabulates with the services offered and demanded. Given that direct clients as corporate bodies or natural persons rank highest it is easily understandable why practices of translations into the $\mathrm{B} / \mathrm{C}$ languages or revision as a separate service do not diminish in frequency. For many direct clients cost related aspects and time constraints often prevail over quality; sadly, the preoccupation for quality may be triggered only by subsequent complaints.

The survey also indicates the level of collaboration with foreign clients, i.e., $20 \%$ of respondents work with EU clients, while 8\% work with clients from all over the world (Cobliş 2008: 143). Though not very high, these rates are indicative of the percentage of translators exposed to strict, clear-cut quality regulations. Often, translators working with foreign (corporate) clients will more likely be convinced to apply quality principles in their daily work and these translators subsequently influence the internal market by introducing quality assurance and quality enhancement procedures also with less demanding clients.

To give an example, a small number of translators have individually, as freelancers, or collectively, through different companies, responded to calls for tenders issued by European institutions for the outsourcing of translations into Romanian. In this situation quality standards have been imposed by the contracting body and no deviation from quality principles is admissible without contract-related consequences. Work in such conditions will positively contribute to the development of a quality culture on the Romanian translation market and one that direct Romanian clients could in time also relate to.

\section{Translation in Romania - the profession}

Translation is clearly a business activity on the Romania market nowadays. The question remains whether within the business a sense of 'the professional' is also developing.

To answer this question, let us evaluate the Romanian market by looking at aspects of professional attitude which can build up, firstly, an individual professional identity and, then, a collective professional conscience governed by professional behavioural patterns developed on ethical principles. Such patterns will be manifested in relation to one's own professional expectations, in relation to fellow-translators, i.e., other members of the professional community, and to clients, i.e., service-buyers. Quality assurance and quality enhancement mechanisms come into play doubled by a strong sense of ethical behaviour.

In what follows, we will see how Romanian translators relate to different language professions and assume different profiles in their marketing strategies, how professional associations contribute to the development of the professional community and what their points of focus are, what standards and guidelines are accepted by the professional community and what attitudes and values will the translators express regarding different aspects of their professional life. 


\subsection{The multitude of language professions}

The 2007 survey conducted by the Romanian Translators Association quoted above (see 3.4) shows clear proof of the range of services that are the subject of supply and demand on the Romanian market. In tune with the diversity of services, language professionals are identifying with distinct professions and will advertise by assuming one professional profile or another, being quite explicit as to the competences that they hold in their marketing campaigns. Clearly, the education sector has taken note of the multitude of language services that are demanded on the market and has responded positively through the training programmes (especially master's level) designed to prepare for the professions of translator, interpreter, terminologist, reviser, subtitler and specialist in localization. Most recently, the economic sector is also reacting as the Classification of Occupations in Romania is being completed with the professions of reviser-lawyer (242915), reviser-linguist (244409) and terminologist $(244410)^{33}$ to complete the already existing list already containing translator (244406) and interpreter (244402). Still one step behind are the legislative regulations awarding professional recognition where no distinction is yet made amongst language professionals with a philology background and those who have specialized translation training, or even amongst different professional language profiles as are translator and interpreter (see 1.1, 1.2, 1.3).

\subsection{Professional Associations}

Out of a sense of belonging and the need for representation, Romanian language professionals have opted to group themselves into professional organizations that look out for their specific interests.

For the purpose of this research I have chosen to examine the activities of a number of associations, ${ }^{34}$ the most representative in shaping professional attitude on the market being the Romanian Translators Association (ATR), the Association of Romanian Translation Agencies (ABTR) and the Romanian Association of Interpreting and Translation Companies (AFIT). The principles for membership and the activities conducted indicate their active preoccupation vis-à-vis the language industry and their constant concern for upgrading the market and serving the translation community by promoting quality services and striving to obtain recognition of professional status.

The Romanian Translators Association (ATR), founded in 2004, comprises to date 150 individual translators and interpreters, as well as corporative and institutional members. The Romanian Translators Association is a full member of the International Federation of Translators (FIT), as well as a full member of the recently created European Legal Interpreters and Translators Association (EULITA). The Romanian Translators Association is represented for the 2008-2011 mandate on the Board of FIT Europe, the Regional European Centre of the International Federation of Translators, and contributes to several FIT Europe working groups. On the Romanian market, some members of the association have been actively involved in the translation of the acquis-communautaire into Romanian and the translation of the CEN standard SR EN 15038. The Romanian Translators Association has provided its members with a Code of Ethics and other guidelines and studies to support their 
professional activity. In 2008, the Romanian Translators Association created a popular free news service for Romanian professional linguists, its ATR Blog being ranked $5^{\text {th }}$ in Lexiophile's Top 10 Language Professionals Blogs 2010. In addition, the Romanian Translators Association has redesigned its website and plans to launch its own online translation magazine. The Romanian Translators Association also organizes conferences, seminars and, most recently, online training sessions, providing continuous professional development as well as community building and networking opportunities for members and non-members. The Romanian Translators Association has recently launched four specialized committees on industry standards, interpreting, legal translation and interpretation and continuous professional development to match the development plans of the association.

The Association of Romanian Translation Agencies (ABTR) was set up in 2005 and comprises a number of five corporate members with turnover of over $€ 170,000$ /year. Membership is limited to members who have a minimum turnover of $€ 50,000$ /year and requires the upholding of ABTR Work Standards and the ABTR Code of Ethics. The Work Standards are designed to ensure the quality of the service to end customers whereas the Code of Ethics provides guidelines for ethical practices in the working community. The Association of Romanian Translation Agencies issues yearly reports about the Romanian translation market based on analysis of turnover figures and market share for translation companies with turnover of over 25,000 €. The Association of Romanian Translation Agencies organizes networking events for translation companies and encourages continuous professional development by planning to organize training activities for members and non-members.

The Association of Interpreting and Translation Companies in Romania (AFIT) was set up in 2005 and is a full member and single Romanian representative of EUATC - European Union of Associations of Translation Companies. The Association of Interpreting and Translation Companies in Romania promotes the development of the national translation market, with a strong emphasis on quality services and the recognition of professional standards. As such, the Association was actively involved in the technical committee of the Romanian Standards Association responsible for the translation of the European standard EN 15038 into Romanian. The Romanian Association of Interpreting and Translation Companies comprises eight corporate members with a substantial market share. The members abide by the Code of Ethics developed by the association and are dedicated to offering quality services on the market by applying SR EN 15038 principles.

\subsection{Standards and Guidelines}

In 2007 the Romanian Standards Association (ASRO) set up a working group to produce a Romanian version of the CEN standard EN 15038 on 'Translation ServicesService Requirements' which had been adopted by the Romanian Standards Association as a national standard. The working group had fifteen members comprising participants representing translation companies (6), professional associations (2), freelancers (2), universities (2), other bodies (2), and ASRO (1). In 2008 SR EN 15038 was finalized and currently it can be purchased to serve as a benchmark for translation service providers, be they translation companies or freelancers, for translation training providers such as higher education institutions or continuous professional 
development training providers, and professional associations in establishing their codes of good practice.

Standards are not regulatory instruments; depending on the country where these are adopted, service-providers will have to undergo a certification procedure by auditing bodies or certify compliance with the standard by self-declaration. Currently, in Romania no official procedure has been developed for the certification of this standard. However SR EN 15038 is well promoted amongst the translation community, especially by the Romanian Translators Association which has organized information campaigns with nationwide participation and has facilitated the distribution of copies to members and non-members. ${ }^{35}$ Additionally, some higher education institutions are already incorporating topics related to the standard in their curricula in more explicit terms such as project management issues and editing and revision practices. ${ }^{36}$ Consequently, we may see in the near future an improved attitude regarding the provision of quality services on the market as translators are bound to become more driven by this benchmark in their everyday activities and clients are bound to become more alert as to what translation services may entail in terms of quality.

Even prior to the SR EN 15038, Romanian professional associations developed their own standards for quality assurance for translation activities as incorporated in the documents members subscribed to: the Deontological Code of the Romanian Translators Association, the Work Standards and the Code of Ethics of the Association of Romanian Translation Companies and the Code of Ethics and the forthcoming Code of Good Practice of the Romanian Association of Interpreting and Translation Companies. These documents serve as guidelines for the general professional community and as regulatory instruments for the members of the professional associations.

Issues addressed in these instruments include the following: the Deontological Code of the Romanian Translators Association ${ }^{37}$ stipulates, amongst other aspects, that the translator must perform only translation tasks from a language that is known and into a language that is native-like to the translator, must translate texts from domains that are familiar to him/her, must become aware of lifelong learning obligations and must undertake continuous professional development for linguistic, domain-specific and technical aspects, must ensure that all necessary resources are available for the translation task, must abide by confidentiality principles, must refer to clients nominally with third parties only after permission has been sought from the client, must subcontract only with the client's approval and with a guarantee that the subcontractor will abide by quality standards imposed; the Work Standards of the Association of Romanian Translation Companies ${ }^{38}$ insist on documented procedures for task commissioning and payment, application of a translation memory or minimum terminological tools for translation, a two-stage translation process to include translation and proofreading, the usage of the unit for payment as 'the source text word,' an employment/collaboration procedure involving testing of the translator's competences, a system of monitoring mistakes and arbitrating complaints; the Code of Ethics of the Romanian Association of Interpreting and Translation Companies $^{39}$ reiterates principles of translator-translator professional support, translator-client confidentiality, competence-based employment, fiscally documented and legally binding practices, quality assurance and quality enhancement, fair competition discouraging disloyal practices that might include dumping prices, untruthful advertising, unprofessional references to other companies, etc. 
Some of the aspects identified and regulated by the standing documents of the professional associations will seem commonsensical to a mature professional community. However for Romania which is still trying to find its proper footing regarding translation practices and where, in spite of the endeavours of professional associations to establish quality mechanism for market practices, we still find unprofessional attitudes and amateurish translation products, such specifications are more than welcome as they represent building blocks for professional practices embedded in a free, fair and competitive market.

\subsection{Attitudes and Values}

In 2010, the students of the European Master's in Translation Studies and Terminology of the Babeş-Bolyai University initiated a project to establish the perception of Romanian translators regarding ethical issues in the profession. The project started out by analyzing different codes of ethics developed by European and international professional bodies, extracting the recurrent issues and comparing them to codes of ethics as developed by Romanian associations. This was the basis for a theoretical evaluation of market attitudes and values. Subsequently, the students completed their internship periods in a number of translation agencies in Cluj-Napoca, where they could witness professional behaviour amongst translators and with clients. Students then noted down practices they found debatable as well as practices they appreciated and produced a questionnaire to support a general market survey on translator attitudes and values. ${ }^{40}$ Some of the problematic aspects contained in the questionnaire were observed as isolated instances whereas others had already been anticipated and duly regulated by professional associations.

Preliminary results reveal the fact that respondents (229 at the time of publishing) highly condemn the following market practices by labelling them 'unethical':

- naming clients as a reference in written (74.9\%) or oral (63.4\%) communication with third parties without gaining permission from the clients;

- accepting specialized-domain commission for which the translator knows already at the time of commissioning that $\mathrm{s} /$ he will not have enough time for proper research and proofreading (81.9\%);

- omitting excerpts of texts with outdated information without consulting the client (77.1\%);

- renegotiating the price after realizing that the translation entails more time and effort than initially evaluated $(72.7 \%)$;

- subcontracting translation commissions to third party translators with less experience and shipping the translation off to the end-client without a proper revision (92.5\%);

- failing to inform the client before the deadline of the fact that the deadline cannot be met (92.5\%);

- delivering a translation without proofreading (77.7\%);

- dividing a lengthy text amongst a number of collaborators without any terminology support, then collating the fragments received from translators into one document failing to harmonize the end product and sending the document obtained to the end-user (91.9\%);

- revising a text in a language for which the translator does not have advanced competences (93.2\%); 
- validating through signature and stamp translations produced by unauthorized translators in a language with which the translator is not familiar (92.8\%).

In relation to the client, the responses provided indicate a relationship of respect and transparency: $97.9 \%$ would call the client back if they realized that the translation already submitted contained a major mistake, $46.9 \%$ would inform the client if they found the translation commissioned already published on the Internet and would charge only the price for revision informing the client of the situation, $70.6 \%$ would adhere to the client's instructions even in cases where they identify a mistake that the client does not want corrected.

Views are split regarding the payment of very low fees to collaborators: $46.3 \%$ find this unethical and $46.3 \%$ consider that this is not related to ethics; also fragmented are the views regarding low prices practised by novice translators who are trying to attract clients: $48.2 \%$ find such behaviour unethical, $38.1 \%$ consider that it is not related to ethics, but rather a characteristic of a free market.

As regards what texts translators would refuse to accept for translation: $76.8 \%$ indicate that they would refuse texts that promote violence, $74.2 \%$ would refuse pornographic materials, $14.7 \%$ would refuse religious texts they do not agree with while $16.3 \%$ would refuse political-ideological texts they do not agree with.

Regarding texts pertaining to specific domains for which the translator has not been previously trained, $67.2 \%$ admit that they would take on the task but they would negotiate a deadline to enable them to research comprehensively, $21.5 \%$ would refuse the commission and $8 \%$ would take on the task if in financial difficulties at the time.

Another highly debatable aspect in the Romanian context is the use of diacritical signs. As an undesirable trait of the computer era, Romanian as a language greatly suffers from failure to use diacritical signs in general as well as professional written communication. As language professionals, $63.5 \%$ of translators feel that this is unethical, while $16.3 \%$ consider that this is not related to ethics but rather a key factor for quality assurance and respect for the main language in translation.

In summary, from the recommendations derived from professional associations and the results of the survey presented we may conclude that the current market is driven by strong ethical principles. The survey shows that there are professionals on the market as freelancers (61.2\%) and in companies (26.5\%) who are fully conscious of the role ethics plays in professional settings and will further raise awareness and provide guidance to their fellow-translators. The fact that the majority of respondents are in the age-group 20-30 (48.9\%) or in the age-group 30-40 (37.4\%), with a declared experience as professional translators of over 6 years experience $(47.1 \%)$ or with 3 to 6 years experience $(31.3 \%)$ shows that both translators at the start of their profession as well as more experienced translators are aware of ethical issues and will take a stand when questioned about their professional beliefs. This is extremely positive for the Romanian market which has yet to reach maturity.

\section{Romanian as a European language - the opportunities}

Clearly, Romania is not a market in isolation. As part of the European Union many opportunities have emerged on the translation market, triggered by free movement of individuals for work and education. As a European language, Romanian is now 
one of the 23 languages which benefit from a special status with European bodies compliant to the multilingual and multicultural approach of the EU.

Romania's accession brought about development at national and European levels in what regards the language professions. For our study it is interesting to see what washback effect the EU accession has on the national market.

\subsection{Training for Romanian in European Higher Education Institutions}

In 2009 the Department of Applied Modern Languages of the Babeş-Bolyai University in Cluj-Napoca launched a study to identify training programmes with Romanian in other European countries; in 2010 a follow-up was conducted. ${ }^{41}$ A total of 71 responses were received from 26 countries throughout Europe which indicated 24 universities offering Romanian and 4 universities considering introducing Romanian. The study results collated with previous knowledge on training in Europe revealed that Romanian is being taught in the majority of European countries, 22 in number at bachelor or master's level, as full programmes (UK, France, Spain, Hungary, Poland) or as modules within different programmes (Austria, Germany, Hungary, UK, Macedonia, Ireland) or as electives of Romanian culture and civilization (Germany, Spain, Austria) and Romanian language - beginner and advanced levels (Belgium, Germany, the Netherlands, Poland, Austria, Hungary, Lithuania etc.). Most of the universities that run such a programme indicated that the programme was set up in the period before Romania's accession (6 responses) or immediately after ( 9 responses). The explicit reasons for setting up these programmes included: express demand by enrollees, language market growth, the change in status for the Romanian language after the EU accession, university collaboration as well as immigration. The student profiles included non-natives of Romanian and natives of Romanian, taught separately or in mixed groups.

This survey clearly shows that as a result of the EU accession interest in the Romanian language has grown. Particular countries receiving Romanian immigrants find Romanian language learning appealing especially for market purposes. Full translation programmes run with Romanian also give the possibility to Romanian natives to perfect their competences in the foreign languages by immersion in the specific culture. In the long run, on the global translation market, non-natives learning Romanian as a B language will manage services of translation from Romanian into their main language; natives of Romanian based abroad, who train in translation, will cover a substantial volume of translation services into Romanian. Hence, Romanian professionals based in Romania are more likely to have to advertise their services more aggressively, especially through online means, but still in keeping with fair market competition and quality-driven principles. Moreover, translations into the B language may slowly become an obsolete practice.

\subsection{Working with Romanian in European institutions}

After Romania's accession to the EU a lot of investment was made in policies of multilingualism and language professions were promoted per se, especially as part of Commissioner Leonard Orban' mandate. ${ }^{42}$ Translators having Romanian as their main language were first employed in translation and interpreting departments of 
EU institutions as temporary agents. As a result of the 2005 EPSO recruitment competition, Romanian language units were set up and later developed to serve the European Commission, the European Parliament, the European Economic and Social Committee, the Committee of the Regions, the European Court of Justice, the Court of Auditors, etc. The results of the most recent EPSO competition for Romanian translators were announced in 2010.

Translators working into Romanian who are not employed at EU level have a good chance to work for EU institutions as freelancers. Statistics of the Directorate General for Translation of the European Commission indicate in 2009 a rate of $22 \%$ volume of translations into Romanian being outsourced to freelancers previously selected through call for tenders. Given that in 2009 the number of pages translated by the DGT into Romanian was slightly under 60,000 we may estimate currently 13,000 pages being outsourced by DGT alone. ${ }^{43}$ However the figures are much higher if we add the freelance translations coming from the other EU institutions and the Translation Centre for the bodies of the EU.

According to EU policy, language professionals are required to work into their main language and only in rare and specific circumstances into their B languages. Hence, Romania's accession to the EU resulted in employees of other language departments of EU institutions taking an interest in Romanian. A parallel survey to the one presented at 5.1, also conducted by the Department of Applied Modern Languages of the Babeş-Bolyai University in Cluj-Napoca requested the European Commission full time and freelance language staff to answer a questionnaire regarding their interest in Romanian as a European language. 26 respondents, permanent staff and freelance collaborators of the Directorate General for Translation and the Directorate General for Interpretation of the European Commission, use Romanian as a $\mathrm{B} / \mathrm{C}$ language. $74 \%$ of respondents had taken up Romanian in the period 2005 2007 by following courses offered as continuous professional development and/or by immersion in the Romanian community life. The predominant reasons for taking up Romanian were: change of status of the Romanian language (90\%), on employer's request (30\%), and Romanian language market growth (24\%).

As a conclusion, European institutions offer a benchmark for translation practices with a clear washback effect on the Romanian language market and the European market, with Romanian being promoted as a European language. As a result, professionals with Romanian as an A language benefit from numerous opportunities, whereas other language professionals are considering Romanian to develop their language profile.

\section{General Conclusions}

After Romania's accession to the European Union, the Romanian translation market witnessed rapid development. With the new status of the Romanian language, translation commissions involving Romanian increased at national level and European level, also in EU institutions.

The purpose of the current research was to establish the characteristics of the Romanian language market to date and to elicit the degree of recognition and professionalization of translation activities. Regrettably, this research endeavour was in part thwarted by a number of difficulties, not least lack of previous properly docu- 
mented research projects, surveys with disappointing response rates and, perhaps most significantly but also more positively, practices substantially changing throughout the research stages, which make the research findings more difficult to pinpoint. For now, the information that exists will have to suffice for an opening report on the situation which will ideally engender both greater awareness and widespread debate on the issues raised.

To sum up our findings we may say that there is appropriate training being conducted, the business is following a standard market pattern and there is a professional community which acknowledges good practice and ethical principles. However, there are still various 'traditional' aspects which have not yet been appropriately addressed and which affect the normal flow of development. Indeed, until the Romanian market reaches a stage where recognition of professional status becomes competence-based and the individual responsibility vis-à-vis the profession is cultivated into improving the professional community towards one that can inspire a sense of belonging, it is very difficult to expect higher levels of response for research initiatives that propose to present this community at face value. When the whole Romanian scene becomes a coherent medium for professional development and all translators enter this profession out of a true sense of motivation, we can then expect the translation community to feel the urge to voice their views also for research purposes.

Such changes that are taking place may validate our findings in the long run or may throw the market off into a different direction. However, it is undeniable that considerable collective effort has been put into the market mix as it stands, and as reported here. It is highly unlikely for any changes, as drastic as they may be, to make the market and the community regress. We hope that further research will confirm this hypothesis.

\section{NOTES}

1. European Institute of Romania - Institutul European din România. Visited on 21 July 2010, <http:// www.ier.ro/index.php/site/page/acquis_comunitar>.

2. Language competence is tested by the Ministry of Culture if the applicants are non-language graduates (see section 1.2).

3. Both master's programmes of the Babeş-Bolyai University, namely the European Master's in Translation Studies and Terminology (<http://www.lett.ubbcluj.ro/mastertt/ $>)$ and the European Master's in Conference Interpreting (<http://masteric.lett.ubbcluj.ro/ >) have European recognition as sole Romanian members of the European Master's in Translation EMT Network of the Directorate General for Translation, European Commission and the European Master's in Conference Interpreting EMCI Consortium in collaboration with DG-SCIC, European Commission and DG-Interpretation of the European Parliament, respectively.

4. Romanian Ministry of Labour, Family and Social Protection - Ministerul Muncii, Familiei şi Protecției Sociale. Visited on 4 August 2010, <http://www.mmuncii.ro/pub/imagemanager/images/ file/COR/190110COR_coduri.pdf>.

5. Holders of a Baccalaureate diploma which stands proof of completion of twelve school forms.

6. Romanian Decision 1291/2002, Law 110/2005 and the latest Ministerial Order 772/2009.

7. Romanian Law 110/2005 amending Law 178/1997 regarding the activity of translators and interpreters employed by legal authorities including the Ministry of Justice, courts and tribunals, notary public offices and attorneys-at-law.

8. Romanian Law 286/2005 completing Law 178/1997.

9. This procedure is, of course, admissible for rare languages for which training programmes do not exist and without any specialist to test the language competence - hence the authorization procedure cannot be fulfilled. 
10. Romanian Law 31/1990 on business organizations.

11. Romanian Law 300/2004 on the activity of sole-traders.

12. Romanian Agency for Qualifications in Higher Education and Partnership with the Economic and Social Environment - Agenția Națională pentru Calificările din Învățământul Superior și Parteneriat cu Mediul Economic şi Social, Proiectul DOCIS. Visited on 3 August 2010, <http://docis.acpart.ro>.

13. European Commission, Directorate General for Translation, European Master's in Translation. Visited on 3 August 2010, <http://ec.europa.eu/dgs/translation/programmes/emt/index_en. htm>.

14. European Commission, Directorate General for Translation, Visiting Translator Scheme. Visited on 3 August 2010, http://ec.europa.eu/dgs/translation/programmes/visiting/index_en.htm.

15. European Commission, Directorate General for Translation, European Master's in Translation. Visited on 3 August 2010, <http://ec.europa.eu/dgs/translation/programmes/emt/network/index_ en.htm>.

16. Romanian Agency for Quality Assurance in Higher Education - Agenția Română de Asigurare a Calității în Învățământul Superior, Standarde Specificie Comisia de Științe Umaniste și Teologie. Visited on 8 August 2010, <http://www.aracis.ro/uploads/media/Standarde_specifice_C02.pdf $>$.

17. While Russian was the main foreign language in training before 1989 , it substantially decreased after 1989 with a slight come-back now after 2007.

18. Romanian Translators Association - Asociația Traducătorilor din România. Visited on 25 July 2010, $<$ http://www.atr.org.ro/formare/seminarii $>$.

19. Romanian Translators Association - Asociația Traducătorilor din România. Visited on 2 August 2010, <http://www.atr.org.ro/formare/webinarii $>$.

20. The International Annual Meeting on Language Arrangements, Documentation and Publications. Visited on 6 August 2010, <http://www.iamladp.org/PDFs/2010_docs/CPD_data_10.pdf >.

21. Regrettably, at the time of publishing, we have no figures allowing us to evaluate the impact of the general economic crisis on the Romanian translation market.

22. Romanian Ministry of Justice - Ministerul Justiției. Visited on 2 August 2010, <http://www.just.ro/ MeniuStanga/Listapersoanelorautorizate/Traducatori/tabid/129/Default.aspx $>$.

23. Association of Romanian Translation Agencies - Asociația Birourilor de Traduceri din România. Visited on 5 August 2010, <http://www.abtr.ro/upload/download/Analiza\%20pietei\%20traduceri lor\%20din\%20Romania\%202008.pdf>.

24. For this survey, respondents with a double status were allowed to choose both categories, i.e. freelancer and in-house (Romanian Translators Association - Asociația Traducătorilor din România, Survey: Romanian Translation Market Trends. Visited on 10 August 2010, <http://www. atr.org.ro/diverse/ATR_TendintePiataTrad_2008.pdf>).

25. Survey Monkey, Survey: Ethics in Translation. Visited on August 10, 2010, <http://www.surveymonkey.com/s/Etica_in_Traducere $>$.

26. Association of Romanian Translation Agencies - Asociația Birourilor de Traduceri din România. Visited on 4 August 2010, <http://www.abtr.ro/en/work_standards.php >.

27. At the time of publishing, the exchange rate for $1 \mathrm{EUR}=4.2 \mathrm{RON}$ and $1 \mathrm{USD}=3.23 \mathrm{RON}$. National Bank of Romania - Banca Națională a României. Visited on 3 August 2010, <http://www.bnr.ro/ Cursul-de-schimb-524.aspx>.

28. Unofficial reports indicate yearly incomes ranging from $€ 3600$ up to $€ 45,000$ for freelancers.

29. Romanian Ministry of Public Finance - Ministerul Finanțelor Publice. Visited on 5 August 2010, $<$ http://apt1.mfinante.ro/site/contribuabili/link.jsp?body=/contribuabili/agenti_nume.htm>.

30. Association of Romanian Translation Agencies - Asociația Birourilor de Traduceri din România. Visited on 6 August 2010, <http://www.abtr.ro/upload/download/Analiza\%20pietei\%20traduceri lor\%20din\%20Romania\%202008.pdf>.

31. Association of Romanian Translation Agencies - Asociația Birourilor de Traduceri din România. Visited on 10 August 2010, <http://www.abtr.ro/en/abtr_analyses.php>.

32. Reproduction authorized by Cristiana Cobliş, president of the Romanian Translators Association.

33. European Institute of Romania - Institutul European din România. Visited on 7 August 2010, $<$ http://www.ier.ro/index.php/site/news_page/254>.

34. As we are focussing on translation-oriented initiatives we will not detail the activities of associations strictly geared on interpreting, as is the Romanian Association of Conference Interpreters. Details can be obtained from <http://aric.3x.ro/>, visited on 3 August 2010.

35. Romanian Translators Association - Asociația Traducătorilor din România. Visited on 2 August 2010, <http://www.atr.org.ro/standardizare >. 
36. Babeş-Bolyai University, Faculty of Letters, European Master's in Translation Studies and Terminology - Universitatea Babeş-Bolyai, Facultate de Litere, Masterat European de TraductologieTerminologie. Visited on 10 August 2010, <http://www.lett.ubbcluj.ro/mastertt/programa.html>.

37. Romanian Translators Association - Asociația Traducătorilor din România. Visited on 2 August 2010, <http://www.atr.org.ro/despre/deontologie>.

38. Association of Romanian Translation Agencies - Asociația Birourilor de Traduceri din România. Visited on 2 August 2010, <http://www.abtr.ro/en/work_standards.php>.

39. Association of Interpreting and Translation Companies in Romania - Asociația Firmelor de Interpretariat şi Traduceri din România. Visited on 2 August 2010, <http://www.afit.ro/page. php? pageid=11>.

40. Survey Monkey, Survey: Ethics in Translation. Visited on 10 August 2010, <http://www.surveymonkey. com/s/Etica_in_Traducere $>$.

41. Survey Monkey, Survey: Romanian Language in European Higher Education. Visited on 10 August 2010, <http://www.surveymonkey.com/s/Romanian_in_HE >.

42. European Commission, Directorate General for Education and Culture, Multilingualism. Visited on 6 August 2010, <http://ec.europa.eu/education/languages/eu-language-policy/index_en.htm>.

43. European Commission, Directorate General for Translation. Visited on 6 August 2010, <http:// ec.europa.eu/dgs/translation/publications/brochures/translation_history_en.pdf>.

\section{REFERENCES}

CoBliş, Cristiana (2008): Status Quo and future trends of the Romanian translation market. Studia Universitatis Babeş-Bolyai Philologia. LIII(3):137-156.

Greere, Anca (2010): Changes to Professional Translator Training in Romania. Liaison Magazine. 4:14.

Greere, Anca (2008): Quality Issues in Romanian Translator and Interpreter Training: Investigating the validity of standards proposed by the Romanian Agency for Quality Assurance in Higher Education [ARACIS]. Studia Universitatis Babeş-Bolyai Philologia. LIII(3):81-94.

Greere, Anca and Tătaru, Cristina (2008): Training for the Translation Profession: What do Romanian University Programmes have to offer? Studia Universitatis Babeş-Bolyai Philologia. LIII(3):95-122.

\section{APPENDIX}

Association of Interpreting and Translation Companies in Romania, Code of Ethics. Visited on 2 August, 2010, <http://www.afit.ro $>$.

Association of Romanian Translation Agencies: Romanian Translation Market Analysis of 2004, 2005, 2006, 2007 and 2008. Visited on 2 August 2010, <http://www.abtr.ro/ro/ analize_abtr.php>.

Association of Romanian Translation Agencies: Work Standards. Visited on 2 August 2010, <http://www.abtr.ro/en/work_standards.php >.

Babeş-Bolyai University of Cluj-Napoca, European Master's in Translation Studies AND TERMINOLOGY. Visited 10 August 2010, <http://www.lett.ubbcluj.ro/mastertt/>.

European Commission, Directorate General for Translation. Visited 4-6 August 2010, $<$ http://ec.europa.eu/dgs/translation $>$.

European Commission, Directorate General for Education and Culture. Visited 6 August 2010, <http://ec.europa.eu/education/>.

European Institute of Romania. Visited 21 July 2010, <http://www.ier.ro $>$.

International Annual Meeting on Language Arrangement, Documentation and Publications IAMLAPD, Universities' Contact Group CPD database. Visited 10 August 2010, <http://www.iamladp.org/ucg.htm>.

Romanian Agency for Qualifications in Higher Education and Partnership with the Economic and Social Environmement. Visited on 2 August 2010, <http://docis.acpart. ro>. 
Romanian Agency for Quality Assurance in Higher Education. Visited 8 August 2010, $<$ http://www.aracis.ro $>$.

Romanian Ministry of Public Finance. Visited on 5 August 2010, <http://www.mfinante.ro>. Romanian Ministry of Justice. Visited 3 August 2010, <http://www.mjust.ro>.

Romanian Ministry of Labour, Family and Social Protection. Visited on 4 August 2010, $<$ http://www.mmuncii.ro $>$.

Romanian Standards Association. Visited on 6 August 2010, <http://www.asro.ro>.

Romanian Translators Association (2008): 2007 Survey on Romanian Translation Market Trends. Visited on 10 August 2010, <http://www.atr.org.ro/diverse/ATR_TendintePiata Trad_2008.pdf>.

Romanian Translators Association (unpublished): 2007 Survey on Recommended Market Fees.

Romanian Translators Association: Deontological Code. Visited 2 August 2010, <http:// www.atr.org.ro/despre/deontologie>. 